\title{
Globalization of mortgage-backed securities market in Russia: Legal impact on transaction economy
}

\author{
Alexander Almosov ${ }^{1}$, Yulia Brekhova ${ }^{2}$, Svetlana Bondareva ${ }^{3}$, and Sofya Sevostyanova ${ }^{4 *}$ \\ ${ }^{1}$ Volgograd Institute of Management, branch of RANEPA, Economic department, 8, Gagarin st. \\ Volgograd, Russia \\ ${ }^{2}$ Volgograd Institute of Management, branch of RANEPA, Economic department, 8, Gagarin st, \\ Volgograd, Russia \\ ${ }^{3}$ Volgograd Institute of Management, branch of RANEPA, Economic department, 8, Gagarin st., \\ Volgograd, Russia \\ ${ }^{4}$ Volgograd Institute of Management, branch of RANEPA, Economic department, 8, Gagarin st., \\ Volgograd, Russia
}

\begin{abstract}
Research background: The exponential growth of mortgage lending has taken on increasing importance in development of securitization activities market for mortgage assets throughout the world. The difficulty of comparing mortgage-backed securities of different countries explained by varying national legal features is the reason why there is no international market for such securities. Since 2014, the mortgage securities market has entered the stage of nationalization; as a result, it slowed down and lost the necessary infrastructure, including its legal components. Since securitization of mortgage loans first originated and became common in developed economies, it is of interest to compare Russian and international experience of legal regulation of each transaction stage.

Purpose of the article: The purpose of this paper is to analyze legal regulation features of mortgage securitization in different countries and their impact on economic characteristics of securities in order to develop a globalization strategy for this market.

Methods: The study is based on open data from Russian, European, American, England Central Banks and uses methods of structural, statistical, dynamic analyses and abstraction which made it possible to form holistic and substantiated conclusions.

Findings \& Value added: As a result of research activities, key features of legal regulation of mortgage securitization transaction have been identified. Based on these findings, a strategy for globalization of mortgage securities market was proposed. It contributes to international cooperation development in the field of long-term projects financing, including support measures of mortgage lenders.
\end{abstract}

Keywords: securitization; mortgage lending; international financial market; globalization

\footnotetext{
*Corresponding author: sevostyanova.sa@ya.ru
} 
JEL Classification: F36; F63; G15; G21

\section{Introduction}

Around the world, the banking sector is traditionally strictly regulated for prudential purposes. The requirements also cover securitization process. The system of legal regulation of securitization includes a set of rules and regulations which determine the ability and obligation to act in accordance with internal model in calculating its regulatory capital requirements. (Svobodová and Hedvičáková, 2021)

Globalization of mortgage securities market helped to enable the rapid growth of issued mortgage loans in Russia, New Zealand, European Union, the USA, Ireland, Norway, Belarus, Kazakhstan, etc. While the asset-backed securitization market is the most mature in developed countries, it still lags far behind the dynamic global growth in particular in emerging markets. On the other hand, the advent of institutional investors in the stock markets has increased the demand for such reliable financial instruments as mortgagebacked securities (Deku et al., 2021). We regard globalization strategy as developmental direction for mortgage-backed securities market at both stages of issuance and circulation. To this end, the authors examined international experience in regulating various stages of securitization transactions. (Teplova et al., 2020)

\section{Methodology}

The objectives of this study are determined by the aim of finding key issues of regulation of securitization stages for uniting markets into a single financial space and include:

- Identification of principal stages of mortgage backed securities transaction;

- Study of legal features of each transaction stage and the impact on economic indicators of the transaction;

- Establishment of fundamental postulates of Globalization Strategy of mortgage securities market.

In this study, we employed a comparative structural analysis to qualitatively assess mortgage backed securities. The methodological apparatus of the research is inseparably incorporated with universalization of securitization transactions due to increase in business globalization.

The research hypothesis is the assumption of existence of a Key Stage implicating the possibility of universalization of both securitization transaction process and securities emission.

\section{Results}

Speaking about regulation of the securitization transaction, we distinguish the following stages that are most universal for each scheme:

- Formation and selection of a mortgage bond portfolio;

- $\quad$ Transfer of legal title for mortgage loans pool;

- New securities' issuing and placing on the primary securities market;

- $\quad$ Trading securities on secondary markets;

- $\quad$ Retirement of mortgage bonds. 


\subsection{Stage of Formation and Selection of Mortgage Bond Portfolio}

In the course of formation and selection of the mortgage loan portfolio, the primary relationship is established between the borrower and the lender, which subsequently forms pools of mortgage loans for securitization transaction. Transfer of the purchased or already pledged property to the bank is a special feature of mortgage loan arrangements. It is this feature that is an advantage over other securitized assets, since the pledge is real property with legally established recovery procedures.

In the United States, relationships between borrowers and lenders are built on the basis of multilateral control of lenders over borrowers and the state over all participants. Mortgage relations in the United States are regulated by common (case) law, federal law and state law. The activities of financial organizations in the lending market are regulated by the Civil Code, Civil Procedure Code, Financial Code, Insurance Code, Federal Law on Mortgages, Law on the Mortgage Corporation of Federal Bank for Internal Loans, Law on Settlement of Real Estate Disputes, etc. Among regulatory authorities, special mention should go to the Federal Reserve System (in terms of supervision and regulation of banks activities to ensure the stability of financial market and protect the rights of borrowers), the National Administration of Credit Unions (designed to control and insure federal credit unions throughout the country) and the Federal Council for Financial Institutions (authorized to establish uniform principles, standards and reporting forms for federal expertise of financial institutions).

The US legal system belongs to the Anglo-Saxon system and therefore the legal regulation in the UK is very similar to the American one. The legal framework is very broad and provides legal entities with contractual freedom. The main legislative acts regulating the process of issuing, servicing a loan and processing the transfer of title of ownership are the following: Financial Services Act, Banking System and National Bank Acts, Financial Services and Markets Act, the EU Mortgage Credit Directive. On the one hand, the legal system is flexible; therefore, contracts are legally enforceable agreements between parties that have the opportunity to include almost any conditions. On the other hand, this forces the parties to provide for all possible scenarios and spend considerable amounts on legal advice.

The countries of the Germanic Legal System (Germany, Sweden, Finland, the Netherlands, etc.) practice Securitization Legislation differently from the Anglo-Saxon ones. The regulations are very detailed and cover all stages of the relationship between the participants in the securitization infrastructure, and also determine the degree of freedom of the parties in the contractual relationship. Distinct limitations in concluded agreement interpreting are a specific for Germanic securitization law in comparison with Anglo-Saxon one. On the one hand, this reduces legal costs on transaction; on the other hand, lack of flexibility of the legal system does not allow a quick response to emerging financial innovations.

The Roman Legal System (France, Belgium, Spain, etc.) is between the two previously considered in terms of legal flexibility. Many areas are sufficiently detailed in the securitization law; however, the prospects are variable and depend greatly on the specific country. Although in general the legislation is quite flexible and easily adaptable to financial innovative implementations.

Application of the Germanic model of mortgage loans is a feature EU regulation. For this reason, the legislative acts structure is similar between countries in the field of relationship regulation between the borrower and the lender regarding the issue and registration of mortgage loans.

The Russian Federation legal system belongs to the Romano-Germanic system and uses less flexible, but more detailed legislative acts. Legal regulation of the issuance and maintenance of mortgage loans in the Russian Federation is based on the following Acts: 
Civil Code, federal laws "On Mortgages (real estate pledges)", "On Consumer Loans" and "On State Registration of Real Estate Rights and Transactions". In addition, there are many legislative acts regulating various interrelated areas, for instance, the Law "On business insurance organization in the Russian Federation", the Housing Code, etc. Generally, Russian legal framework is more similar to that of European countries, since in many respects the mortgage lending system itself is based on the experience of these countries (Diaz-Serrano, 2019).

\subsection{The stage of Transfer of Legal Title for Mortgage Loan Pool}

The stage of transfer of legal title for mortgage pool is specific for each jurisdiction. Here, transfer regulation of legal rights to the formed mortgage loans pool is of fundamental importance. In case of absence of regulation or double interpretation opportunities in securitization transaction process, there are significant risks for all participants that the law imposes a presumption that the transaction is recognized as void and the title returns to the originator. It is at this particular stage that the need for adoption of special securitization legislation arises.

The American housing finance system is a two-tier system, in which the first tier belongs to commercial banks that issue mortgages, and the second to special mortgage agencies (Ginnie Mae, Fannie Mae and Freddie Mac), the purpose of which is to buy out mortgages from banks and issue them on their basis securities backed by these mortgages. These agencies provide security for mortgage-backed bonds, standardize and maintain resilience of the secondary market. Due to US government policy, securitization has become a tool to increase banks liquidity since the first issues of mortgage-backed bonds. The special legislative regulation system enabled simplification and popularization of this process and includes the following Acts: Federal Home Loan Bank Act, the Federal Home Loan Mortgage Corporation Act, the Home Mortgage Disclosure Act, Securitization and Reconstruction of Financial Assets and Enforcement of Security Interest Act.

Different standard protocol of transaction in Europe and the United States assures the main difference between securitization processes (Balcerzak et al., 2018) In the United States, Special Purpose Vehicles (hereinafter SPVs) in the form of various types of trusts are created, to which assets are transferred, directly providing the investors with a share in the trust. In Europe, however, standard forms of legal entities are predominantly used as SPVs, to which assets are sold and then securities are issued (Hedvicakova and Pozdilkova, 2018). The fundamental difference between an SPV in the form of a Legal Entity and a Trust is a simplified procedure for the creation and functioning of a Trust which does not arise by virtue of state registration, but, as a rule, by virtue of the transfer of assets to the trustee and his consent to act as such. Despite the fact that the Trust is not a legal entity, it has a separate segregated property, it is able to be a plaintiff and a defendant in court with the help of trust managers, the bankruptcy procedure is applicable to it, and subsequently the trust can be transformed into any other commercial organization. In European countries, the practice of regulating this stage is more multidirectional so in order to present data and to compare legal conditions, the following table is used

Table 1. Legal support features of transfer of legal title for mortgage loan pool in European countries

\begin{tabular}{|c|c|c|c|}
\hline Country & $\begin{array}{c}\text { Securitizatio } \\
\text { n volume, } \\
\mathbf{2 0 2 0}, \text { bn } \\
\text { US dollars }\end{array}$ & $\begin{array}{c}\text { SPV organizational } \\
\text { and legal form }\end{array}$ & $\begin{array}{c}\text { Difficulties in securitization } \\
\text { process }\end{array}$ \\
\hline Great Britain & 55,46 & Trust & $\begin{array}{c}\text { Prevalence of business } \\
\text { securitization schemes over other } \\
\text { types }\end{array}$ \\
\hline
\end{tabular}




\begin{tabular}{|c|c|c|c|}
\hline Netherlands & 38,68 & $\begin{array}{l}\text { Stock or limited } \\
\text { liability Company }\end{array}$ & $\begin{array}{l}\text { The need to notify borrowers about } \\
\text { a change of lender. } \\
\text { Special mechanisms are needed to } \\
\text { transfer the title from the security to } \\
\text { the Trust. }\end{array}$ \\
\hline Italy & 44,84 & $\begin{array}{c}\text { Limited liability } \\
\text { company }\end{array}$ & Exposure of SPV to bankruptcy \\
\hline Germany & 42,36 & $\begin{array}{c}\text { Does not apply SPV } \\
\text { mechanism }\end{array}$ & $\begin{array}{l}\text { Assignment of receivables is } \\
\text { possible only after their occurrence. } \\
\text { The need for licensing of the } \\
\text { service organization. }\end{array}$ \\
\hline France & 36,58 & $\begin{array}{l}\text { Fonds Commun de } \\
\text { Créances (FCC) } \\
\text { (Joint fund of } \\
\text { liabilities) }\end{array}$ & $\begin{array}{l}\text { Difficulties in establishing } \\
\text { structures for secured loans caused } \\
\text { by legislative provisions on } \\
\text { collateral and sequencing of rights } \\
\text { to collateral }\end{array}$ \\
\hline Belgium & 13,25 & $\begin{array}{l}\text { Mennootschap voor } \\
\text { Belegging in } \\
\text { Schuldvorderingen } \\
\text { naar Belgische recht } \\
\text { (VBS) (Debt } \\
\text { Investment Mutual } \\
\text { Fund) }\end{array}$ & ( \\
\hline Portugal & 18,99 & $\begin{array}{c}\text { Fundos de } \\
\text { Titularização de } \\
\text { Créditos (Asset } \\
\text { Securitization Fund); } \\
\text { Sociedade de Titulari } \\
\text { zaçao de Créditos } \\
\text { (Asset Securitization } \\
\text { Company). }\end{array}$ & High cost of the Operation \\
\hline
\end{tabular}

Source: author (2021)

There is a practice of special legal entity's opening in a jurisdiction other than the originator, where it is established as an ordinary company operating within the framework of traditional corporate law, but having special legal capacity and not subject to certain types of taxes. Predominantly, these tax incentives and special legal capacity status are developed within the framework of special legislation governing securitization transactions. This is partly why Russian securitization market faced the need to develop special legislation in this area. The adoption of Russian securitization law has marked a turning point for the financial market and caused the following fundamental changes in the system:

- $\quad$ Securitized assets types diversified;

- Transferring possibility of the title to the creditor can be confirmed (true sale);

- New legal forms of companies, analogues of special legal entities are created;

- The subject of pledge was expanded and there is confirmation of the assets pledge validity, as well as execution priority of creditors' claims in the event of implementation;

- The concepts of Nominal, Escrow and Collateral Accounts were introduced. The latter contains assets subject to bonds collateral.

It should be stated that there is no special securitization law as such in any country. As a rule, this is a group of legislative acts and amendments which are collectively used by the infrastructure participants to conduct securitization transactions. However, the EU Securitization Regulation adopted in 2019 was a step towards the establishment of a unified legal framework for securitization in European countries and eliminated the uncertainty in 
accounting and reserve requirements for securitization issues (Foote et al., 2020). The main feature of the new Act was the introduction of regulation on "simple, transparent and comparable" securitization and the interest rates reform, thus moving away from LIBOR, and establishing transparent rules for investment in the European market (Fiordelisi and Galloppo, 2018)

\subsection{New Securities`Issuing Stage}

The stage of new securities' issuing and placing them on the primary market consists in selling the mortgage loans pool to a mortgage agent or specially created legal entity that issues bonds backed by this pool. At this stage, the issue is structured, the return rate, maturity date and risks level is determined; rating is assigned, and mechanisms for improving the credit quality are selected. It can be argued that further issue, attractiveness of these securities for investors and stability to emerging risks depend wildly on the characteristics adopted at this stage.

The process of mortgage bonds issuing in the United States is based on the Securities Act of 1933, the Securities Act of 1934 and Article 8 of the Uniform Commercial Code of the United States. Overall, the very procedure for the issue and placement of securities is of a standard nature with an exception of options for participants' composition. The U.S. Securities and Exchange Commission established under the Securities Exchange Act of 1934 is the main body that supervises and regulates the American securities market. The securities market participants are regulated by the following Acts: On Securities, On Trust Deed, On Investment Companies, On Investment Advisors and the Sarbanes-Oxley Act.

On a supranational scale, the EU Council of Economic and Social Affairs and the European Securities and Markets Authority Commissions regulate the securities market in European nations. There are additional supranational bodies in the field of securities market regulation that are not regulators in the full sense. For instance, the Financial Stability Council unites regulators of stock markets in more than 100 countries (90 per cent global securities markets). Bank for International Settlements, International Swaps and Derivatives Association, International Securities Market Association should also be named among the organizations involved in the development of standards and rules in the financial services market (Huan and Parbonetti, 2019).

At the same time, there is no single body regulating the securities market in the EU. Accordingly, internal functioning issues of the securities market are resolved at the national level. At the same time, the legal regulation analysis of the stage of new securities ' issuing and placing them on the primary market in European countries did not reveal any fundamental national specific features. Besides, the authors have identified legal universalization trend implemented through single EU regulations implying unconditionally direct action and not requiring national adoption. The EU legislation provides, if necessary, immediate and uniform regulation of public relations in the stock market.

Unlike European legislation, Russian financial market regulation is not universal, but segmental in nature. The Federal Law "On the Securities Market" is the main regulatory act governing the Russian Federation securities market, defining rights and obligations of the subjects, as well as procedure and features of various securities issue. The circulation of mortgage bonds is regulated by the federal law "On mortgage securities", "On Amendments to Certain Legislative Acts of the Russian Federation in Connection with the Transfer to the Central Bank of the Russian Federation of Powers of Regulation, Control and Supervision in the Sphere of Financial Markets", etc. According to the last named federal law, the activity on regulation of securitization in the Russian Federation since 2013 belongs to the Central Bank of the Russian Federation. However, based on the results of eight years of experience in regulation, it is difficult to understand the intentions of the 
Central Bank of the Russian Federation in terms of regulating securitization. We can say that during this period there were no significant shifts towards the popularization or simplification of the securitization procedure, even if we take into account the entry into force of the Federal Law "On Amendments to Certain Legislative Acts of the Russian Federation", the so-called "Law on Securitization".

\subsection{Stage of Trading Securities on Secondary Markets}

The legal regulation of the stage of securities' floating in the secondary market is practically identical to the previous stage, with the exception of the need to resolve situations occurring with mortgage loans (early repayment, default and refinancing).

The degree of prudential supervision of such securities also plays an important role here. Attractiveness as a destination for overseas investment and freedom of circulation depend on how cautiously the Central Bank or another regulator treats them. For example, in Russia, in the process of introducing Basel III standard requirements, the highest operational risk assessment for mortgage bonds were used which forced some capital providers to refuse to invest in them and, largely, slowed down the development of the national securitization market.

\subsection{Stage of Retirement of Mortgage Bonds}

All SPV receivables closure and its bankruptcy are of paramount importance at the stage of retirement of mortgage bonds. If senior bonds issued by the mortgage agent are amortized to an extent that the load on the issuer's infrastructure is incomparable with the expected yield on junior tranche bonds, originators prefer to early repay mortgage-backed securities of all classes.

After retirement of bonds and alienation of mortgages, the issuer begins the liquidation procedure. Timely formation of the final register of the mortgage agent's accounts is an important point at which payment must be affected before liquidation in order to correctly calculate the coupon for junior tranche. At the same time, the issuer must have enough funds to pay for mandatory services to third parties (commissions to banks, notary fees, etc.). Rretirement of each specific issue is a unique project even within the same legal framework (Frankel, 2002).

On the basis of legal regulation analysis of securitization procedure in Russia and in other countries, a system of main stages and relation regulated at each of them was formed. The dependence of development level of asset securitization market in the country with the presence of legal regulation of the stage of transfer of claims for a pool of mortgage loans was revealed. It turned out that in countries with a low level development of securitization market, regulation of this stage is unstable, and in some cases it combines legal shortcomings with clearly regulated areas. The reason for this dependence was the violation of several fundamental principles of securitization at once in the absence of clear regulation of this stage (principle of the transaction protection from bankruptcy of the originating bank and / or SPV; principle of legal separation of assets from SPV; principle of legal collateral use to cover issued bonds; principle of using heritable securities in the property rights role).

In Russian science of economics, globalization images are usually built on the ideas of a post-industrial and (or) digital society crowned by digital economy. The authors have identified three main postulates of the globalization strategy of the mortgage securities market on the basis of analysis of the mortgage securitization stages, including:

- Specific universal rules are developed in the area of monetary claims assignment in favor of SPVs as well as detailed regulations for the SPVs monetary claims servicing; 
- Strict rules are introduced into the regulatory framework in order to prevent the initial creditor from challenging SPV transactions in addition to other mechanisms that ensure the status of the SPV as a bankruptcy remote entity;

- Fundamental standards of "simple, transparent and comparable" securitization is applied along with the Basel III regulation implementation, however, national market features are taken into account.

As a result, established that reduction of investment risks through diversification as well use of best global practices in the area assure positive perspectives for creating a global market for mortgage-backed securities.

\section{Discussion}

The fundamental postulates of Globalization Strategy of mortgage securities market are established by the authors on the basis of these features developing international relations in the field of financing long-term projects, including participants in the mortgage lending market. It has been determined that perspective of global market creation for mortgagebacked securities considerably reduces investment risks of in this area through investments diversification and exchange of Russian and international experience of legal regulation of each transaction stage.

As a result of the study, the authors confirm the hypothesis put forward about the existence of a Key Stage implicating the possibility of universalization of both securitization transaction process transferring claims to a pool of mortgage loans and securities emission.

The issues of financial market globalization are revealed in the works of such researchers as: Baron M., Verner E., Xiong W. (Baron et al., 2021), Moshirian F., Tian X., Zhang B., Zhang W. (Moshirian et al., 2020), who also come to the conclusion about the need to regulate this process. On the other hand, such scientist as Duarte F., Eisenbach T.M. (Duarte and Eisenbach, 2021), Heimer R., Simsek A. (Heimer and Simsek, 2018), Ahlstrom D., Arregle JL, Hitt MA, Qian G., Ma X., Faems D. (Ahlstrom et al., 2020) identify numerous contradictions and risks in this process. However, according to global trends, the later point of view is not confirmed. On the contrary, globalization strategy can become the basis for risk management of the mortgage assets market.

\section{Conclusion}

The present paper contributes to the securitization studies, firstly, by focusing on current data as an indicator of research value; secondly, by using European securitization market sample. This is relevant because most researchers of securitization markets are exclusively committed to the United States experience which is not always applicable nationally. Moreover, the securitization emergence in Europe was mainly caused by certain market forces, and was not a government-sponsored campaign as is the case in the United States. Thirdly, in this paper the authors introduce a conceptual idea of market development in order to add value to augmented knowledge not limiting the research by consideration of isolated cases.

Securitization at its core is a complex and lengthy process that requires legislative regulation of each step in the process of its implementation. As a rule, when preparing the first securitization transactions, the parties involved are faced with many controversial issues regarding interpretation of legal norms at different transaction stages. Increasing popularity of securitization transactions in the country takes on increasing importance of specific law adoption establishing the ground for such transactions. The government, which 
prioritizes the securitization market development, adopts regulations of financial assets securitization. If the legislator is not interested in the market development, the securitization transaction participants are force to use foreign jurisdictions that are most suitable for specific transaction parameters.

\section{References}

1. Ahlstrom, D., Arregle, J.-L., Hitt, M.A., Qian, G., Ma, X., \& Faems, D. (2020). Managing technological, sociopolitical, and institutional change in the new normal. Journal of Management Studies, 57(3), 411-437.

2. Balcerzak, A. P., Kliestik T., Streimikiene D., \& Smrcka L. (2018). Non-parametric approach to measuring the efficiency of banking sectors in European Union countries. Acta Polytechnica Hungarica, 14, 51-70.

3. Baron, M., Verner, E., \& Xiong, W. (2021). Banking crises without panics. Quarterly Journal of Economics, 136(1), 51-113.

4. Deku, S. Y., Kara, A., \& Karimov, N. (2021). Do investors value frequent issuers in securitization? Review of Quantitative Finance and Accounting, 57(4), 1-36.

5. Diaz-Serrano, L. (2019). Inflation of home appraisal values and the access to mortgage loans of credit constrained borrowers. International Review of Economics \& Finance, 63(SI), 412-422.

6. Duarte, F., \& Eisenbach, T.M. (2021). Fire-sale spillovers and systemic risk. The Journal of Finance, 76(3), 1251-1294.

7. Fiordelisi, F., \& Galloppo, G. (2018). Stock market reaction to policy interventions. In The European Journal of Finance, 24, 1817-1834.

8. Foote, C. L., Loewenstein, L., \& Willen, P.S. (2020). Cross-Sectional patterns of mortgage debt during the housing boom: Evidence and implications. The Review of Economic Studies, 88(1), 229-259.

9. Frankel, T. (2002). The law of cross-border securitization: Lex Juris. Duke Journal of Comparative and International Law, 12, 475-492.

10. Hedvicakova, M., \& Pozdilkova, A. (2018). The development of mortgage loans with using regression analysis. Journal of Engineering and Applied Sciences, 13(9), 70037007.

11. Heimer, R., \& Simsek, A. (2019). Should retail investors' leverage be limited? Journal of Financial Economics, 132(3), 1-21.

12. Moshirian, F., Tian, X., Zhang, B., \& Zhang, W. (2020). Stock market liberalization and innovation. Journal of Financial Economics, 2.

13. Svobodová, L., \& Hedvičáková, M. (2021). Mortgage loans and impacts of the global pandemic COVID-19 in the globalized society. SHS Web of Conferences, 92.

14. Teplova, T., Sokolova, T., \& Gubareva, M. (2020). Perception and drivers of financial constraints for the sustainable development. Sustainability, 12(17), 1-38.

15. Huan, X., \& Parbonetti, A. (2019). Financial derivatives and bank risk: Evidence from eighteen developed markets. Accounting and Business Research, 1-28. 